\title{
Estimation of stature from head length in western Indian Gujarati adolescent population
}

\author{
Ritesh K. Shah ${ }^{1}$, Sanjaykumar D Kanani ${ }^{2, *}$, Bharat G Patel ${ }^{3}$, Jayshree N Tolani ${ }^{4}$ \\ ${ }^{1}$ Associate Professor, ${ }^{2}$ Assistant Professor, ${ }^{3}$ Professor, ${ }^{4}$ Tutor cum Statistician, ${ }^{1,2,3}$ Dept. of Anatomy, ${ }^{4}$ Dept. of \\ Community Medicine, ${ }^{1,3,4} \mathrm{GCS}$ Medical College, Ahmedabad, Gujarat, ${ }^{2}$ GMERS medical College, Himmatnagar, \\ Gujarat, India
}

*Corresponding Author:

Email: drsanjaykanani@gmail.com

\begin{abstract}
Introduction and Objectives: Stature is a very useful indicator of a person's physical identity. One of the main objective of forensic investigation is establishing the identity especially when body parts are missing or mutilated. Stature estimation is an important step in positive identification of a person's identity and various body parameters can be used to correctly estimate the stature. The current study was aimed at developing regression equations and to find out correlation between stature and head length in Gujarati adolescent population.

Material and Methods: The study was conducted in 150 apparently healthy, adolescent medical students from various regions of Gujarat, India. The age of subjects ranged between 18 to 22 years. Head length and stature of the selected subjects were measured in erect posture. Obtained data were analysed to find correlation and derive regression equations for estimation of stature from head length.

Result: The mean stature and head length was significantly different in males and females. Both the mean stature and mean head length were higher in males than females. Pearson's correlation between stature and head length was significantly positive in both the sexes. We were also able to derive linear regression equations to correctly predict stature from the head length.

Conclusion: Significant positive correlation was found between stature and head length in the present study. We also present the gender specific regression equation models in order to estimate the stature from the head length in Gujarati adolescent population.
\end{abstract}

Keywords: Correlation, Head length, Stature.

Received: $23^{\text {rd }}$ August, 2017

\section{Introduction}

Estimation of stature is one of the most important step in determining the identity of unknown, highly decomposed or mutilated human bodies as stature is one of the most important anthropometric parameter that determines the physical identity of an individual. Stature like other body parameters is determined by many factors such as genetics, environment and nutrition etc. ${ }^{1}$ Stature has definite and proportional relationship with each and every part of human body and this relationship varies greatly in people of different area, race, ethnicity etc. By measuring the different body parts and stature of the healthy subjects, one can use the regression analysis method which is universally accepted to provide the best estimates for stature calculation for accurately predicting the stature in particular population or race. ${ }^{2}$

Establishment of identity is paramount in forensic examination where only some parts or fragments of the body are available. This is usually seen in incidents like earthquake, bomb blast, aeroplane crash, mutilation by animal etc., where calculating the stature correctly can prove to be a major step forward in establishing personal identity of an individual. Many studies have been done in the past to estimate the stature from various body parameters such as long bones, hand length, hand breadth, foot length, arm span etc ${ }^{3-14}$ but it has been found that cranial dimensions are more reliable in predicting the stature correctly. ${ }^{15-17}$ The aim of the current study was to establish the anthropometric correlation between stature and head length and to derive regression equations for correct estimation of stature in Gujarati adolescent population. The linear regression equations derived from this study can give the investigator an opportunity to estimate the height of an individual from the head length in forensic investigations. Determining an individual's physical description is also very useful in anthropological studies as well.

\section{Material and Methods}

For current study, total 150 apparently healthy, adolescent medical students from 
different parts of Gujarat and the age ranged between 18 to 22 years. Out of 150, 72 were boys and 78 were girls. Necessary permission was taken from Institutional authorities. Stature was measured in standing erect anatomical position vertically in midline from heel to vertex. Head length was measured as a straight distance from the glabella to the opisthocranion using the spreading caliper (Fig. 1). All the measurements were taken in centimetres and during fixed time of the day to avoid any diurnal variation and by the same person to avoid personal error in methodology. Obtained data was statistically analysed by linear regression analysis.

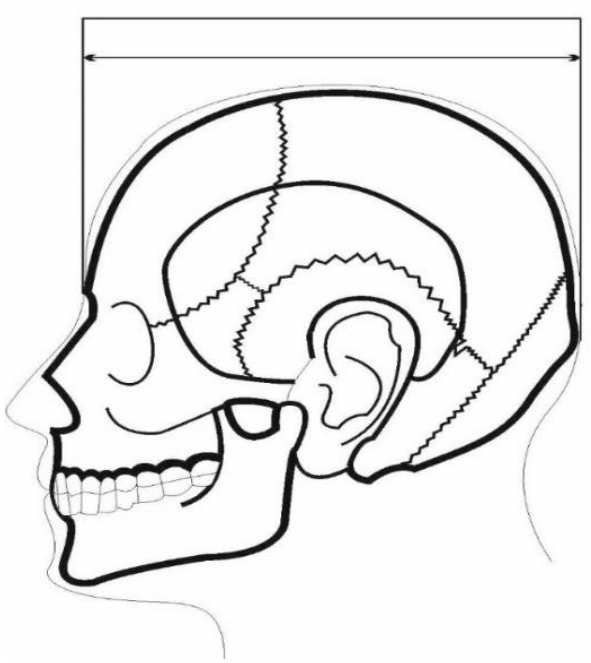

Fig.1: Showing measurement of head length as a straight distance from glabella to opisthocranion

\section{Results}

Table 1. Statistical analysis of stature and head length measurements in all subjects

\begin{tabular}{|c|c|c|c|c|c|c|}
\hline & \multicolumn{2}{|c|}{ All (Male and Female) } & \multicolumn{2}{|c|}{ Male } & \multicolumn{2}{|c|}{ Female } \\
\hline & $\begin{array}{c}\text { Stature } \\
(\mathbf{c m})\end{array}$ & $\begin{array}{l}\text { Head length } \\
\text { (cm) }\end{array}$ & $\begin{array}{c}\text { Stature } \\
(\mathbf{c m})\end{array}$ & $\begin{array}{l}\text { Head length } \\
(\mathrm{cm})\end{array}$ & $\begin{array}{c}\text { Stature } \\
(\mathbf{c m})\end{array}$ & $\begin{array}{l}\text { Head length } \\
\text { (cm) }\end{array}$ \\
\hline Range $(\mathrm{cm})$ & 144.2-191 & $16.2-20.5$ & $158.8-191$ & $17.3-20.5$ & $144.2-174.5$ & $16.2-18.7$ \\
\hline $\operatorname{Mean}(\mathrm{cm})$ & 168.234 & 18.183 & 175.947 & 18.553 & 161.114 & 17.841 \\
\hline $\begin{array}{l}\text { Standard } \\
\text { Deviation } \\
\text { (SD) } \\
\end{array}$ & 9.396 & 0.675 & 5.917 & 0.604 & 5.620 & 0.547 \\
\hline $\begin{array}{l}\text { Correlation } \\
\text { (r) }\end{array}$ & \multicolumn{2}{|c|}{$0.662(\mathrm{p}=0.000)$} & \multicolumn{2}{|c|}{$0.262(\mathrm{p}=0.026)$} & \multicolumn{2}{|c|}{$0.692(\mathrm{p}=0.000)$} \\
\hline $\begin{array}{l}\text { Regression } \\
\text { Co-efficient } \\
\text { (b) }\end{array}$ & \multicolumn{2}{|c|}{9.207} & \multicolumn{2}{|c|}{2.521} & \multicolumn{2}{|c|}{7.109} \\
\hline $\begin{array}{l}\text { Constant of } \\
\text { Regression } \\
\text { equation(a) }\end{array}$ & \multicolumn{2}{|c|}{0.822} & \multicolumn{2}{|c|}{129.173} & \multicolumn{2}{|c|}{34.290} \\
\hline
\end{tabular}

As shown in Table 1, head length varied from $17.3 \mathrm{~cm}$ to $20.5 \mathrm{~cm}$ with an average of $18.553 \pm$ $0.604 \mathrm{~cm}$ of SD whereas the stature in males varied from $158.8 \mathrm{~cm}$ to $191 \mathrm{~cm}$ with an average of $175.947 \pm 5.917 \mathrm{~cm} \mathrm{SD}$. In females, head length ranged from $16.2 \mathrm{~cm}$ to $18.7 \mathrm{~cm}$ with mean head length of $17.841 \pm 0.547 \mathrm{~cm} \mathrm{SD}$, while the stature ranged from $144.2 \mathrm{~cm}$ to $174.5 \mathrm{~cm}$ with mean stature of $161.114 \pm 5.620 \mathrm{~cm} \mathrm{SD}$.

The linear regression analysis of the obtained data has provided the regression equations for the estimation of stature and are as follows:

Stature $(\mathrm{ST})=$ value of constant $(\mathrm{a})+$ [regression coefficient $(\mathrm{b}) \mathrm{x}$ head length (HL)]

For all (male and female): $\mathrm{ST}=0.822+9.207(\mathrm{HL})$

For male: $\mathrm{ST}=129.173+2.521(\mathrm{HL})$

For female: $\mathrm{ST}=34.290+7.109(\mathrm{HL})$ 
Table 2: Comparison of measured stature with estimated stature from head length

\begin{tabular}{|c|c|c|c|c|}
\hline \multirow{2}{*}{ Variable } & \multicolumn{2}{|c|}{$\begin{array}{c}\text { Estimated Stature (cm) using } \\
\text { Regression equation }\end{array}$} & $\begin{array}{c}\text { P value } \\
\text { representing the } \\
\text { significance of } \\
\text { difference between } \\
\text { the measured } \\
\text { stature and the } \\
\text { estimated stature }\end{array}$ & $\begin{array}{c}\text { Standard } \\
\text { error of } \\
\text { estimation } \\
\text { (SEE) }\end{array}$ \\
\hline All & $149.975-189.566$ & $168.229 \pm 6.218$ & $\begin{array}{c}0.994 \\
\text { (Not significant) }\end{array}$ & 0.3258 \\
\hline Males & $172.786-180.854$ & $175.945 \pm 1.523$ & $\begin{array}{c}0.997 \\
\text { (Not significant) }\end{array}$ & 0.1833 \\
\hline Females & $149.456-167.228$ & $161.222 \pm 3.891$ & $\begin{array}{c}0.987 \\
\text { (Not significant) }\end{array}$ & 0.0375 \\
\hline
\end{tabular}

Table 2 shows the comparison between the estimated stature and actual stature. The difference between the estimated stature and actual stature is non-significant. So, it can be said that stature can be predicted near accurately from head length using the regression equations.

\section{Discussion}

The estimation of stature from measurements of various parameters such as long bones, foot, hand, arm span, head has been attempted previously. Every race or population is different genetically and there by having differences in body parameters and therefore data analysis of one race or population cannot be applied to the others. Further, when the body is mutilated or only few body parts are available for examination, an accurate estimate of stature can be made if the relationship of different body parameters with stature is known in a particular race or population.

Table 3. Comparison of studies done by various authors

\begin{tabular}{|c|c|c|c|c|c|}
\hline & & $\begin{array}{c}\text { Stature Mean } \pm \\
\text { SD }(\mathrm{cm})\end{array}$ & $\begin{array}{c}\text { HL Mean } \\
(\mathrm{cm})\end{array}$ & $\begin{array}{c}\text { Correlation } \\
\text { coefficient }\end{array}$ & $P$ value \\
\hline \multirow{2}{*}{ Chaurasia et al ${ }^{18}$} & $\mathrm{M}$ & $170.905 \pm 11.339$ & $18.420 \pm 1.272$ & 0.241 & 0.000 \\
\hline & $\mathrm{F}$ & $153.374 \pm 20.544$ & $17.260 \pm 0.597$ & 0.173 & 0.006 \\
\hline \multirow{2}{*}{ Ilayperuma et al 19} & $\mathrm{M}$ & $162.95 \pm 9.025$ & $18.0 \pm 1.112$ & 0.715 & --- \\
\hline & $\mathrm{F}$ & $152.48 \pm 11.498$ & $17.19 \pm 1.011$ & 0.470 & --- \\
\hline \multirow{2}{*}{ Kalia $S$ et al ${ }^{20}$} & $\mathrm{M}$ & $171.6 \pm 5.578$ & $17.6 \pm 0.95$ & 0.13 & 0.009 \\
\hline & $\mathrm{F}$ & $155.67 \pm 5.266$ & $16.4 \pm 0.59$ & 0.00 & 0.712 \\
\hline Krishnan K ${ }^{21}$ & $\mathrm{M}$ & $172.31 \pm 6.83$ & $17.832 \pm 0.892$ & 0.775 & $<0.001$ \\
\hline Zakia A et al ${ }^{22}$ & $\mathrm{~F}$ & $152.79 \pm 5.62$ & $17.49 \pm 0.58$ & & 0.774 \\
\hline \multirow{2}{*}{ Santosh Kumar et al ${ }^{23}$} & $\mathrm{M}$ & $170.432 \pm 4.6$ & $18.047 \pm 2.54$ & 0.941 & --- \\
\hline & $\mathrm{F}$ & $157.32 \pm 3.58$ & $16.921 \pm 1.56$ & 0.85 & --- \\
\hline \multirow{2}{*}{ Agnihotri et al ${ }^{24}$} & M & $173.4 \pm 7.70$ & $18.66 \pm 0.79$ & 0.331 & 0.004 \\
\hline & $\mathrm{F}$ & $157.36 \pm 6.17$ & $18.13 \pm 0.91$ & 0.159 & 0.176 \\
\hline \multirow{2}{*}{ Mahesh kumar et al ${ }^{25}$} & M & - & $18.75 \pm 1.386$ & 0.174 & 0.0004 \\
\hline & $\mathrm{F}$ & - & $17.75 \pm 0.847$ & 0.190 & 0.0001 \\
\hline \multirow{2}{*}{ Present study } & $\mathrm{M}$ & $175.947 \pm 5.917$ & $18.553 \pm 0.604$ & 0.262 & 0.026 \\
\hline & $\mathrm{F}$ & $161.114 \pm 5.620$ & $17.841 \pm 0.547$ & 0.692 & 0.000 \\
\hline
\end{tabular}

$\mathrm{M}=$ Male, $\mathrm{F}=$ Female, $\mathrm{HL}=$ Head length

As shown in Table 3, the mean head lengths measured in this study were greater than Chaurasia RS et al, ${ }^{18}$ Ilayperuma I et al, ${ }^{19}$ Kalia S et al, ${ }^{20}$ Krishan K, ${ }^{21}$ Zakia et al, ${ }^{22}$ Santosh Kumar et $\mathrm{al},{ }^{23}$ but it was smaller than Agnihotri AK et $\mathrm{al}^{24}$ \& Maheshkumar et $\mathrm{al}^{25}$ (male subjects) which indicates that cranial morphometry is greatly dependent on variety of factors like race, age, nutritional factors etc. Although variety of methods have been used to estimate stature from various bone dimensions, regression analysis is one of the easiest as well as reliable method. Correlation coefficients between stature and head length in present study was 0.662 for all subjects, 0.262 for males and 0.692 for females. 
Previous studies have shown correlation coefficient for males to be 0.241 by Chaurasia RS et al., ${ }^{18} 0.715$ by Ilayperuma $\mathrm{I}^{19} 0.13$ by Kalia $\mathrm{S}$ et al., ${ }^{20} 0.775$ by Krishan $\mathrm{K},{ }^{21} 0.941$ by Santosh Kumar et al., ${ }^{23} 0.331$ by Agnihotri AK et al., ${ }^{24}$ and 0.174 by Maheshkumar et al. ${ }^{25}$ Correlation coefficient for males in our study was found to be 0.262 which is more than that of Chaurasia RS et al., ${ }^{18}$ Kalia $S$ et al., ${ }^{20}$ and Maheshkumar et $\mathrm{al}^{25}$ but it is less than correlation coefficient derived in the studies of Ilayperuma I, ${ }^{19}$ Krishan $\mathrm{K},{ }^{21}$ Agnihotri AK et al. ${ }^{24}$ and Santosh Kumar et al. ${ }^{23}$ Similarly, in previous studies correlation coefficient for females was found to be 0.173 by Chaurasia RS et al., ${ }^{18} 0.470$ by Ilayperuma I, ${ }^{19} 0.00$ by Kalia $S$ et al., ${ }^{20} 0.850$ by Santosh Kumar et al., ${ }^{23} 0.159$ by Agnihotri et al., ${ }^{24}$ and 0.190 by Maheshkumar et $a .^{25}$ In the study of Zakia An et al..$^{22}$ on Bangladeshi Garo adult females correlation between head length and stature was not significant while in our study we found a significant correlation $(r=0.692)$ between head length and stature. It is known that sexual dimorphism is an important factor producing morphological variations in biological populations. ${ }^{26}$ The same gender divergence in cranial morphometry was also seen in the present as well as previous studies. In the present study, gender specific regression equations are obtained for adolescent population of western Indian Gujarati population.

Variety of factors such as age, race, gender and nutritional status affect the development and growth of the body and therefore separate regression models are required not only for the different populations but also for different genders within the same population. Therefore, we derived separate regression equations for all subjects, males and females. Using those regression equations, we were able to calculate the estimated stature from the measured head length. A comparison was made between measured stature and estimated stature and there was no significant difference between the measured and estimated stature for the head length. This indicates the effectiveness of the corresponding regression equation in the estimation of stature.

It is stated that racial characters are best defined in the skull. ${ }^{27}$ Cranial dimensions constitute most important character for determining racial difference. ${ }^{27}$ Stature varies greatly in different race. Based on this statistical analysis, it was found that head length is a good parameter to predict the stature correctly. This result further confirm that the cranial morphometric analysis provides precise and good means in stature prediction. One should also remember that even though the regression equations show good accuracy, there would always be some error in estimation of stature.

\section{Conclusion}

The present study was carried out to investigate the possibility of estimating the stature of a person from head length by application of regression analysis. The regression equations derived were found to be fairly effective as estimated stature did not differ much from the measured stature and can be used in medico-legal, anthropological and clinical scenarios. As these data are population specific, the data of one population cannot be applied to other population or region.

\section{References}

1. Nat BS. Estimation of stature from long bones in Indians of the United Province: A medicolegal inquiry in anthropometry. Indian J Med. Res, 1931;18:1245-63.

2. M.Y. Iscan, Forensic anthropology of sex and body size. Forensic Sci. Int. 147 (2005) 107-112.

3. Dupertuis CW \&Hadden JA. On the reconstruction of stature from long bones. Am J Phys Anthropol, 195;9:15-53.

4. Allbrook D. The estimation of stature in British and East African males, J Forensic Medicine, 1961; 8: 15-28.

5. Athawale NC. Estimation of height from length of forearm bones- A study of one hundred Maharashtrian male adults of ages between 25-30 years. Am J Phys Anthropol, 1963;21:105-12.

6. Singh B \&Sohal HS. Estimation of stature from clavicle in Punjabis. A preliminary report. Indian Journal of Medical Research. 1951;40:67-71.

7. Krishan K. Estimation of stature from footprint and foot outline dimensions in Gujjars of North India. Forensic Sci Int 2008;175:93-101

8. Pawar PK, Dadhich A. Study of correlation between height and hand length in residents of Mumbai. Int. J Biol Med Res. 2012;3(3):20712075.

9. Hossain $\mathrm{S}$ et al. Measurement of stature from arm span - An anthropometric study on Garo tribal Bangladeshi females. Bang J Anat. 2011:9(1):5-9.

10. Khanpurkar S \& Radke A. Estimation of stature from the measurement of foot length, hand length and head length in Maharashtra region. IJBAMR, 2012;1(2):77-85

11. Jasuja OP \& Singh G. Estimation of stature from hand and phalange length. JIAFM,2004;26(3):100-6.

12. Bhatnagar DP, Thapar SP, Batish MK. Identification of personal height from the somatometry of the hand in Punjabi males, Forensic Science Internation, 1984;24:137-41.

13. Saxena SK. A study of correlation and estimation of stature from hand length, hand breadth and sole length, Anthropol ANZ,1984;42(4):271-76. 
14. Sanli SG, Kizilkanat ED, BoyanOzsahin NE, M. Bozkir MG, Soames R, Erol H \&Oguz O. Stature estimation based on hand length and foot length. ClinAnat, 2005;18:589-96.

15. Jadav HR, Shah GV. Determination of the personal height from the length of the head in Gujarat Region. J Anat Soc Ind 2004;5(1):20-1.

16. Patil KR, Modi RN. Determination of sex by discriminant functional analysis and stature by regression analysis: A lateral cephalometric study. Foren Sci Int 2005;147:175-80.

17. Saxena HK et al. The estimation of stature from head length. Journal of anatomical society of India.1979;28:53.

18. Chaurasia RS, Bamne A, Shukla SN, Gohiya V, Pandey R. Estimation of stature from head length. International Journal of Medical Science Research and Practice.2014;1(2):40-3.

19. Ilayperuma I. On the prediction of personal stature from cranial dimensions. Int. J. Morphol. 2010;28(4):1135-40.

20. Kalia, S., Shetty, S., Patil, K., Mahima, V., Stature estimation using odontometry and skull anthropometry. Indian Journal of Dental Research [online], 2008;19(2):150-4.

21. Krishan K. Estimation of stature from cephalofacial anthropometry in north Indian population. Forensic Science International 2008;181:52.e152.e6.

22. Zakia A et al. Stature estimation using head measurements in Bangladeshi Garo adult females. Bangladesh J of Anatomy. July 2009; Vol 7 (2):101-04.

23. Santosh Kumar, Rohin Garg, Khushboo Mogra, Rajuram Chaudhary. Prediction of stature by the measurement of head length in population of Rajasthan. Journal of Evolution of Medical and Dental Sciences. 2013;2(14):2334-40.

24. Agnihotri AK et al. Estimation of stature from cephalo-facial dimensions by regression analysis in Indo-Mauritian population. J of Forensic and leg Med. 2011;18:167-72.

25. Mahesh Kumar \& Patnaik VV Gopichand. Estimation of stature from cephalo-facial anthropometry in 800 Haryanvi adults. Int $\mathrm{J}$ of plant animal and environmental sciences. 2013;3(2):42-6.

26. Williams, P. L., Bannister, L. H., Berry, M. M., Collins,P., Dyson, M., Dussek, J. E. Gray's Anatomy: The anatomical basis of medicine and surgery. 38th Ed. New York, Churchill Livingstone, 2000.

27. Krishan K. Anthropometry in Forensic Medicine and Forensic Science-'Forensic Anthropometry'. Int. J. Foren. Sci. 2007, 2:1. 